\title{
Dampak Sosial Media Bagi Pembinaan Anak dalam Keluarga
}

\author{
Syarifa Raehana, Jufri M.Zein \\ Email : raehana@umi.ac.id \\ Dosen Tetap Universitas Muslim Indonesia
}

\begin{abstract}
Abstrak
Tujuan Penelitian ini untuk mengetahui pengaruh sosial media terhadap perkembangan perilaku anak dan dampaknya bagi pembinaan anak dalam keluarga. Kajian ini menggunakan pendekatan kualitatif dengan metode studi kasus.Simpulan dari penelitian ini bahwa penggunaan sosial media memiliki dampak postif dan negatif bagi siswa. Dengan adanya media sosial dapat dijadikan sebagai alat untuk meningkatkan keharmonissan dalam lingkup rumah tangga. Media sosial dapat dijadikan saran untuk mempererat silaturahmi antar keluarga. Dibutuhkan kebijaksanaan ornag tua dalam mendidik anak agar anak menggunakan media sosial dengan cerdas, untuk dimanfaatkan dalam rangka meningkatkan potensi dirinya. Perlu ada keseimbangan antara pengguna media sosial dan menjaga keharmonisan keluarga.
\end{abstract}

\section{Kata Kunci : Sosial Media, Pembinaan Anak, Keluarga.}

\section{Pendahuluan}

Perkembangan sosial media selalu mempunyai "dua sisi mata uang”. Satu sisi, sangat membantu dalam meringankan urusan masyarakat dalam mengakses dan mencari informasi dengan sangat mudah. Namun disisi lain sosial media dapat merugikan masyarakat itu sendiri dengan menjadi sarana untuk penyebaran Informasi yang tidak benar (Agus SB, 2016)

Instrumen terkecil dalam struktur masyarakat dengan tingkat penggunaan media sosial terbanyak adalah dikalangan remaja atau anak, namun penggunaan serta pengaruh perkembangan media sosial secara continue akan berdampak negatif bagi pola perilaku dan perkembangan anak dalam kesehariannya, anak-anak cenderung terus-menerus menggunakan media sosial untuk berkomunikasi tanpa kenal waktu dan sangat tergantung serta menjadi kegiatan yang harus dan rutin dilakukan oleh anak dalam aktifitas sehari-hari, tidak dipungkiri saat ini anak-anak lebih sering bermain media sosial dari pada belajar dan berinterkasi dengan lingkungan sekitarnya, baik linggkungan sekolah terutama dilinggkungan keluarga.

Keluarga merupakan sebuah institusi terkecil di dalam masyarakat yang berfungsi sebagai wahana untuk mewujudkan kehidupan yang tentram, aman, damai, sejahtera dan harmoni dalam suasan cinta dan kasih sayang diantara anggotanya (Mufidah, 2013).

Keluarga yang kokoh adalah keluarga yang menciptakan generasi penerus berkualitas, berkarakter kuat, dalam hal ini adalah anak. Ketika menyeru dan memberi gambaran tentang indahnya hubungan keluarga yang harmonis, Islam memperlihatkan berbagai fungsi serta menunjukkan buah manisnya kehidupan keluarga yang akan memiliki implikasi terhadap kehidupan keluarga baik orang tua dan anak sebagai wujud nikmat dan karunia Allah swt. 
Gangguan dan masalah dalam hubungan keluarga antara orang tua dan anak mutlak adanya, gangguan persoalan yang dihadapi anak dalam keluarga lebih kepada perilaku anak dalam interaksi sosial serta percepatan informasi dan komunikasi dengan penggunaan media sosial dalam mempengaruhi perkembangan serta implikasinya terhadap hubungan interkasi dilingkungan keluarga.

Maka untuk dapat mengetahui pengaruh media sosial serta kaitannya dengan perkembangan dan hubungan anak dan orang tua dilingkungan keluarga, selayaknya penulis dapat meneliti dan menganalisa permasalahan dalam bentuk penelitian.

\section{Tinjauan Pustaka}

\section{A. Tinjauan Umum Media Sosial}

Lahirnya media sosial sendiri bermula pada era 70-an, tepatnya tahun 1978, saat sistem papan buletin atau bulletin board system (BBS) ditemukan oleh Ward Christensen dan Randy Suess yang merupakan pecinta dunia komputer. Sistem papan ini memungkinkan pengguna (user) untuk bisa berhubungan dengan orang lain memakai surat elektronik atau pun mengunggah dan mengunduh melalui perangkat lunak yang tersedia saat itu. Ini merupakan awal sebuah komunikasi virtual dalam lingkup terbatas. Kala itu konektivitas internet berlanggsung menggunakan saluran telepon yang terhubung dengan modem (Burhan Mungin, 2015).

Pada tahun 1998 Google muncul sebagai mesin pencari utama di internet dan memunculkan tampilan indeks. Laju perkembangan jejaring sosial begitu evolutif. Tahun 1999 muncul situs yang dapat digunakan untuk membuat blog pribadi, yaitu Blogger. Situs ini memberi peluang kepada penggunanya untuk dapat membuat halaman situs sendiri. Dengan demikian pengguna Blogger bisa memuat halaman blognya dengan berbagai informasi, seperti hal atau pengalaman bersifat pribadi dan ide, kritik serta pendapatnya mengenai suatu topik persoalan yang sedang hangat.

Kemudian pada tahun 2001, wikipedia, sebuah ensiklopedia online dan wiki terbesar di dunia muncul. Berikutnya tahun 2002, muncul Friendster sebagai situs anak muda pertama yang semula disediakan untuk tempat pencarian jodoh. Konektivitas dalam jaringan maya menjadi awal untuk kemudian dapat disusul dengan temu darat. Oleh karena itu, situs ini lebih diminati anak muda untuk saling berkenalan dan berkomunikasi. Friendster mengalami booming dan kehadirannya begitu fonumenal.

Dalam waktu singkat bermunculan media sosial interaktif lain menyusul friendster. Seakan friendster tidak dibiarkan eksisi sendirian dalam jangka waktu lama, karena sejak 2003 terus bermunculan berbagai medsos dengan bermacam keunggulan, keunikan, karaktersitik dan segmentasi yang beragam. Linkedln yang lahir tahun 2003, muncul semata-mata tidak hanya bersosialisasi saja. Situs ini juga bermanfaat untuk bertukar informasi mengenai pekerjaan atau mencari pekerjaan, sehingga fungsi media sosial makin berkembang. 


\section{Hasil Penelitian}

Berdasarkan hasil penelitian, sosial media memberi pengaruh yang positif dan negatif terhadap anak. Sebagian besar informan siswa menggunakan gadget untuk bersosial media lebiih dari 5 jam. Dan berdasarkan penelitian yang dilakukan, waktu yang mereka gunakan untuk menggunakan sosial media mereka lebih banyak dari pada waktu yang mereka gunakan untuk belajar dalam seharinya. Secara umum mereka mengalami masalah pada interaksi sosial mereka. Sebagian besar diantaranya lebih memilih menghabiskan waktu untuk bersosial media dari pada bermain, bercengkerama secara fisik bersama teman-teman seumuran mereka.

Wawancara yang dilakukan, mayoritas siswa lebih memilih untuk berdiam di rumahnya yang ditemani oleh media sosial mereka dari pada keluar rumah dan bermain bersama teman dan tetangga mereka.

Keluasan informasi dan ketidakmampuan mereka untuk membendung informasi-informasi dalam sosial media juga akan berdampak terhadap mereka. Banyak informasi-informasi negatif bisa dikonsumsi secara mentah oleh anak usia remaja yang bisa berpengaruh terhadap mindset atau pola piker mereka bahkan sampai pada cara mereka dalam bertindak dan mengespresikan sesuatu., diantaranya adalah informasi hoax sampai pada link-link situs porno menjadi bagian dari pertukaran informasi yang bisa didapatkan melalui media sosial.

Pengaruh positif dari penggunaan sosial media siswa SMP 3 Sungguminasa diantarnya melahirkan sikap disimplin oleh para siswa dalam menaati aturan sekolah maupun aturan di rumah. Para siswa SMP 3 Sungguminasa tidak pernah membawa smartphone yang mereka miliki ke sekolah, mereka hanya menggunakan smartphone mereka diluar dari kegiatan belajar seperti di rumah, diluar lingkungan sekolah atau ketika mereka memiliki tugas sesuai peritah guru mereka untuk menggunakan handphone. Ini dikarenakan sekolah melarang untuk membawa smartphone yang akan mengganggu kegiatan belajar mengajar. Para siswa mematuhi aturan yang diterapkan di sekolah mereka sehingga mereka berlaku jujur dengan tidak membawa smartphone ke sekolah mereka.

Sosial media merupakan sarana unntuk mendapatkan informasi dari berbagai pihak. Diantara informasi-informasi yang disebarluaskan di media sosial, terdapat informasi-informasi yang bersifat posistif dan informative yang dapat menambah pengetahuan, pemahaman serta wacana ilmu pengetahuan terkait informasi positif yang mereka dapatkan

\section{Pembahasan Penelitian}

Manusia adalah makhluk yang tidak dapat hidup tanpa kehadiran manusia lainnya. Hal ini mengharuskan kita untuk saling berinteraksi dengan baik antara sesama. Jika kita sibuk dengan sosial media, bagaimana interaksi yang baik akan terjadi? Waktu yang seharusnya kita gunakan untuk bertatap muka langsung dan mengobrol, habis terpakai untuk berselancar dunia maya. Banyak para remaja yang lebih menghabiskan waktu dengan menggunakan sosial media tanpa memperhatikan keadaan disekitar mereka. Usia remaja mereka juga penting untuk digunakan untuk bermain dengan teman sebaya mereka. Selain untuk memenuhi kebutuhan psikologis mereka, usia remaja juga berada pada fase pengenalan karakter. Dengan bermain bersama teman yang sebaya dengan mereka, para siswa 
juga secara tidak langsung diajarkan agar bisa dan tau bagaimmana caranya memperlakukan orang, baik sesuai dengan usia mereka, maupun yang berada diatas dari usia mereka. Dan itu bisa dipelajari dengan berinteraksi sosial di sekitar lingkungan mereka tinggal. Akan tetapi kenyataannya, kebanyakan dari mereka memilih untuk berdiam diri di rumah ditemani dengan hanphone mereka yang bisa memberikan mereka akses untuk menghabiskan waktu mereka di rumah dengan segala fitur yang terdapat dalam hanphone mereka, termasuk media sosial.

Anak usia remaja belum mampu secara matang dan mapan menentukan siapa saja pihak maupun person yang layak mereka kenal dan mereka gauli. Sedangkan Media sosial memberikan akses kepada anak usia dini untuk bisa mengenal semua orang diberbagai belahan dunia. Ketika mereka mengenal seseorang yang kurang bermoral melalui sosial media, hal tersebut juga akan memberikan mereka dampak yang signifikan kepada kualitas moral mereka, mengingat mereka masih berada pada usia rentan yang belum memiliki kematangan dalam berpikir dan bertindak.

Sebagai pihak yang paling bertanggung jawab terhadap tumbuh kembang anak, orang tua seharusnya memberikan bimbingan langsung ketika media sosial tidak mampu digunakan secara bijak oleh anak serta terus mengawasi agar informasi-informasi yang diakses oleh anak merupakan informasi yang positif dan sesuai dengan usia mereka. Penggunaan media sosial yang berada dibawah asuhaan dan pengawasan orang tua mampu memberikan dampak yang baik untuk anak. Secara tidak langsung kita dapat mengajarkan kepada mereka sikap disiplin dan sikap bijaksana melalui kebolehan menggunakan media sosial di rumah. Orang tua bisa membuat perjanjian-perjanjian kepada anaknya untuk tidak menggunakan atau mengkases media sosial diwaktu-waktu yang terlarang.

Pengawasan dari pihak orang tua terhadap penggunaan media sosial yang dilakukan oleh sang anak sangat penting. Keluasan dan tidak terbendungnya informasi-informasi yang beredar pada laman media sosial bisa memberikan dampak yang signifikan terhadap perkembangan anak pada usia remaja. Sebagai orang tua harus mengetahui apa-apa saja yang diakses oleh anak kita di media sosial, dengan cara yang baik dan tanpa ada kesan untuk mengekang kebebasan sang anak. Misalkan email yang terdapat pada akun youtube mereka menggunakan email milik orang tua. Jadi apa saja yang mereka akses di youtube dapat kita ketahui dengan cara mengakses email kita sendiri.

Dibutuhkan kebijaksanaan ornag tua dalam mendidik anak agar anak menggunakan media sosial dengan cerdas, untuk dimanfaatkan dalam rangka meningkatkan potensi dirinya. Perlu ada keseimbangan antara pengguna media sosial dan menjaga keharmonisan keluarga.

\section{Penutup}

Sosial media merupakan produk teknologi yang memberi pengaruh kepada penggunanya. Ia bagaikan pisau bermata dua yang membawa pengaruh positif maupun negatif. Pengaruh yang ditimbulkan bergantung pada sikap pengguna serta perhatian orang tua terhadap anak dalam menggunakan sosial media yang dimilikinya. 
Hendaknya orang tua menyadari bahwa keberadaan media sosial yang merupakan produk teknologi, tidak dapat dihindari apalagi antipati. Orang tua diharapkan secara bijakana dalam mendidik anak agar cesara cerdas menggunakan media sosial agar dapat memberi manfaat sebanyak banyaknya untuk kemajuan dirinya.

\section{Daftar Pustaka}

Hasballah, Fachruddin. 2007. Psikologi Keluarga dalam Islam. Banda Aceh: Yayasan Pena.

Mufidah. 2013. Psikologi Keluarga Islam Berwawasan Gender. Malang: UIN Maliki Press.

SB, Agus. 2016. Deradikalisasi Dunia Maya Mencegah Simbiosis Terorisme dan Media. Jakarta: Daulat Press. 